\title{
URGENSI PERLINDUNGAN HUKUM TERHADAP PRODUK UMKM DI DESA KLARI
}

\author{
Zarisnov Arafat \\ Program Studi Hukum Fakultas Hukum \\ Universitas Buana Perjuangan Karawang
}

Email: zarisnov@ubpkarawang.ac.id

\begin{abstract}
ABSTRAK
Tingginya nilai upah minimum regional Kabupaten Karawang memicu banyaknya keinginan angkatan kerja untuk bekerja di sektor industri sebagai pekerja perusahaan yang berdomisili di Kabupaten Karawang. Desa Klari sebagai salah satu desa yang terletak di Kabupaten Karawang turut mengalami laju pertumbuhan penduduk yang begitu pesat didominasi dengan para pendatang dari luar Karawang yang berkeinginan bekerja di sektor tersebut. Hal itu dianggap sebagai peluang usaha terutama di bidang kuliner bagi beberapa pihak, karena tingginya tingkat konsumsi masyarakat di Karawang, sehingga mendorong banyaknya produk makanan yang diproduksi melalui UMKM. Namun pada kenyataannya banyak wirausahawan (UMKM) yang belum mengetahui bentuk perlindungan hukum terhadap merk produk makanannya yang mana memunculkan polemik untuk menjaga orisinalitas produk mereka sebab mulai banyaknya produk makanan tiruan, sehingga harus diberikan pemahaman kepada mereka. Metode pengabdian yang digunakan adalah Participatory Rural Appraisal (APR) dengan cara bersama-sama menganalisis masalah kehidupan untuk meningkatkan pengetahuan masyarakat sehingga mammpu membuat rencana dan melakukan tindakan nyata. Diharapkan dengan pemberian pemahaman atas pentingnya pendaftaran merk dagang tersebut, dapat menjaga orisinalitas produk ketika terjadi persaingan usaha dengan produk yang sama.
\end{abstract}

Kata Kunci : Perlindungan Hukum, Merk Dagang,

Masyarakat.

ABSTRACT

The high value of regional minimum wages in Karawang Regency has triggered the desire of the workforce to work in the industrial sector as company workers domiciled in Karawang Regency. Klari Village as one of the villages located in Karawang Regency has also experienced a rapid population growth rate dominated by migrants from outside Karawang who wish to work in this sector. This is considered as a business opportunity, especially in the food sector, for several parties, due to the high level of public consumption in Karawang, thus encouraging the number of food products produced through a.k.a UMKM. But in fact, many entrepreneurs do not yet know the form of legal protection for their food product brands, which raises a polemic to maintain the originality of their products because there are many counterfeit food products, so they must be given an understanding. The service method used is Participatory Rural Appraisal (APR) by jointly analyzing life problems to increase community knowledge so that they can make plans and take real action. It is hoped that by providing an understanding of the importance of trademark registration, it can maintain product originality when there is business competition with the same product. 
Zarisnov Arafat

Vol. 3 No 2, Agustus 2021

ISSN 2657-0203

e-ISSN 2686-0244

Keywords: Legal Protection, Trademark, Society

3|Jurnal Buana Pengabdian 


\section{PENDAHULUAN}

Desa Klari di Kabupaten Karawang merupakan desa yang mempunyai luas wilayah $301.476 \mathrm{~km}^{2}$ dengan jumlah total penduduk 7.625 jiwa yang mana pekerjaan penduduk didominasi oleh buruh harian lepas dan karyawan perusahaan swasta. ${ }^{1}$ Banyaknya alih fungsi lahan dari persawahan menjadi kawasan industri di Kabupaten Karawang membuat Desa Klari terdampak laju pertumbuhan penduduk begitu pesat dikarenakan banyaknya penduduk yang datang dari luar Karawang dan menetap di Karawang dengan tujuan mencari pekerjaan sebagai pekerja pabrik.

Perputaran ekonomi di Desa Klari berkembang pesat, terbukti dengan banyaknya pedagang ataupun wirausahawan yang mencoba merubah pola fikir (mindset) warga Desa Klari untuk membuka usaha di sektor perdagangan atau perniagaan. Hal itu juga ditunjang dengan sifat konsumtif masyarakat, sehingga sebagian masyarakat melihat ini sebagai peluang yang dapat dioptimalkan, mengingat semakin beratnya persaingan

\footnotetext{
${ }^{1}$ prodeskel.binapemdes.kemendagri.go.id
}

mendapatkan pekerjaan dan masih rendahnya serapan tenaga kerja sehingga masih tingginya tingkat pengangguran terbuka di Kabupaten Karawang. Bidang usaha yang mulai banyak dikembangkan oleh masyarakat di Desa Klari adalah usaha kuliner dalam bentuk Usaha Mikro, Kecil dan Menengah (UMKM). Dengan adanya bentuk usaha-usaha tersebut secara perlahan-lahan mampu mengurangi tingkat pengangguran di Desa Klari.

Banyaknya produk kuliner yang muncul dari pengembangan UMKM membuat masyarakat Desa Klari bergeliat dalam berkreasi dan berinovasi memproduksi makanan, namun hal tersebut juga menimbulkan permasalahan yang harus mulai disikapi. Banyaknya produk kuliner yang sama dalam bentuk penyajian dan pengemasannya mulai menjadi masalah yang baru, mengingat hal tersebut dapat menghilangkan sifat orisinalitas dari produk pelopornya sendiri, sehingga masyarakat juga bingung dalam membeli produk makanan tersebut, tidak khayal bahwa ada juga masyarakat yang terkecoh dalam membeli produk karena ada kemiripan atau kesamaan pelabelan namun 
berbeda kualitas dari produk tersebut, kegiatan perdagangan barang dan/atau apalagi jika produk tersebut mulai jasa. ${ }^{2}$ Adapun fungsi dari merk adalah: dikenal masyarakat dengan label tertentu, kekhawatiran yang terjadi adalah ketika ada pihak yang membuat produk tiruan dan menggunakan label yang sama namun memiliki kualitas produk yang berbeda.

Oleh karena itu seharusnya para usahawan makanan memberikan merek pada produk yang mereka produksi dan mendaftarkan merek dagang tersebut ke Direktorat Jenderal Kekayaan Intelektual Kementerian Hukum dan Hak Asasi Manusia (DJKI Kemenkumham) untuk menghindari permasalahan yang akan terjadi seperti yang telah penulis sampaikan sebelumnya. Merek merupakan tanda yang dapat ditampilkan secara grafis berupa gambar, logo, nama, kata, huruf, angka, susunan warna, dalam bentuk 2 (dua) dimensi dan/atau 3

\{tiga) dimensi, suara, hologram, atau kombinasi dari 2 (dua) atau lebih unsur tersebut untuk membedakan barang dan/atau jasa yang diproduksi oleh orang atau badan hukum dalam
1. Tanda pengenal untuk membedakan hasil produksi yang dihasilkan seseorang atau beberapa orang secara bersama-sama atau badan hukum dengan produksi orang lain atau badan hukum lainnya;

2. Alat promosi, sehingga mempromosikan hasil produksinya cukup dengan menyebut merknya;

3. Jaminan atas mutu barangnya;

4. Penunjuk asal barang/jasa dihasilkan. $^{3}$

Adapun contoh produk makanan yang banyak diproduksi di Desa Klari seperti rengginang (dikenal masyarakat dengan nama ranginang) yang mulai menjamur diproduksi di Desa Klari namun tidak memiliki ciri khas tertentu dan pelabelan tertentu, selain itu juga produksi tahu baso sebagai salah satu

${ }^{2}$ Pasal 1 angka 1 Undang-Undang Nomor 20 Tahun 2016 tentang Merek dan Indikasi Geografis dan Ahmadi Miru, Hukum Merek Cara Mudah Mempelajari Undang-Undang Merek, PT. RajaGrafindo Persada, Jakarta, 2005, hlm. 3 .

${ }^{3}$ www.dgip.go.id 
panganan yang cukup diminati dan mengalami problematika yang sama dengan jenis makanan sebelumnya.

Maka dari itu, menurut penulis perlu adanya pemberian pemahaman perlindungan hukum terhadap usahawan UMKM yang memproduksi makanan di Desa Klari sehingga usaha tersebut dapat berkembang dan menghindari dari perselisihan hukum di kemudian hari. Adapun kegiatan yang dapat dilakukan untuk mewujudkan hal tersebut adalah dengan penyuluhan pentingnya pendaftaran merek dagang kepada penggiat usaha kuliner di Desa Klari.

\section{METODE}

Program pengabdian kepada masyarakat ini dilaksanakan di Desa Klari dengan melibatkan unsur pemerintahan desa dan lembaga yang terkait (Lembaga Pemberdayaan Masyarakat). Dalam kegiatan pengabdian ini mengundang beberapa usahawan UMKM di Desa Klari khususnya di bidang kuliner agar kegiatan ini tepat sasaran kepada kelompok masyarakat yang memang membutuhkan pengetahuan dan pemahaman tentang pentingnya merek.

\section{Participatory Rural Appraisal} (PRA) atau pemahaman partisipatif kondisi masyarakat di desa merupakan pendekatan yang digunakan di dalam kegiatan ini dengan mengajak masyarakat secara bersama-sama menganalisis masalah kehidupan dalam rangka merumuskan perencanaan dan kebijakan secara nyata. Pada intinya pendekatan ini memungkinkan masyarakat untuk saling berbagi informasi dan meningkatkan pengetahuan mereka tentang kondisi dan kehidupannya serta membuat rencana dan tindakan nyata.

Perencanaan partisipatif yang dilakukan adalah pelatihan pendaftaran merek dagang terhadap produk makanan yang mereka produksi, sehingga bagi mereka yang telah mengetahui dan memahami cara pendaftaran merek dagang dapat membantu anggota masyarakat lainnya yang belum memahami cara mendaftarkan merek dagang mereka. Pelaksanaan program dibagi menjadi 2 (dua) bagian, yaitu:

1. Tahap identifikasi kebutuhan ilmu hukum di masyarakat;

2. Tahap praktek dan pendampingan; 
Adapun jumlah peserta 10 (sepuluh) orang terdiri dari 5 (lima) orang usahawan UMKM dan 5 (lima) orang lagi dari unsur pemerintahan desa dibantu dengan beberapa orang mahasiswa yang sedang mengikuti kegiatan Kuliah Kerja Nyata (KKN) Universitas Buana Perjuangan Karawang, adapun alasan minimnya jumlah peserta dari kegiatan ini tidak terlepas karena kondisi Pandemi Covid19, yang mengharuskan tidak ada kerumunan massa dan wajib menjalankan standar protokol kesehatan. Sehingga dengan bantuan dari pihak pemerintahan desa dan beberapa mahasiswa yang memahami bidang pemasaran serta bidang Informasi dan Teknologi (IT), penulis berharap hasil yang diinginkan dari program kegiatan pengabdian ini agar para usahawan UMKM dapat membuat label produk yang menarik sehingga memudahkan dalam proses penjualan produknya dan mampu mendaftarkan merek dagangnya ke Dirjen HKI Kemenkumham sehingga terjamin perlindungan hukum terhadap merk produk yang sudah didaftarkan agar bagi pihak yang melakukan kegiatan meniru produk yang diciptakan dapat

ditindak secara hukum.

\section{HASIL DAN PEMBAHASAN}

Pada kegiatan pengabdian pada masyarakat ini, penulis melakukan penyuluhan pentingnya pendaftaran merek dagang kepada penggiat usaha kuliner di Desa Klari. Adapun hal yang dilakukan pertama dengan menjelaskan kedudukan UMKM sebagai motor penggerak perekonomian desa sekaligus upaya untuk membantu Pemerintah Daerah mengurangi pengangguran dengan cara menyerap tenaga kerja di desa yang tidak memiliki skill tertentu dan keterbatasan pada tingkat pendidikan formal yang ditempuh juga pentingnya pendaftaran merek bagi produk UMKM sebagai salah satu upaya perlindungan hukum terhadap usahawan/pelaku UMKM.

Usaha Mikro Kecil dan Menengah atau yang kita kenal dengan UMKM turut berkontribusi dalam perekonomian negara. Keberadaan UMKM telah tersebar di seluruh penjuru negeri, memperluas lapangan pekerjaan dan penyerapan tenaga kerja. Semakin banyaknya masyarakat yang berkecimpung di UMKM, tidak serta 
merta tidak menimbulkan masalah. Permasalahan merek merupakan salah satu contoh yang sering terjadi. Anggapan bahwa perlindungan merek tidak berdampak secara signifikan, membutuhkan biaya besar dan proses yang panjang membuat usahawan UMKM kurang peduli dan tanggap untuk mendaftarkan merek dagangnya, padahal, hal ini akan merugikan pelaku usaha UMKM. Konsep dasar pemberian hak merek adalah bahwa merek termasuk obyek kekayaan intelektual. Merek sebagai hak milik yang lahir dari kemampuan intelektual manusia melalui daya cipta dan karsa, dengan pengorbanan tenaga, pikiran, waktu dan biaya, yang menjadikan karya tersebut bernilai ekonomis. Nilai ekonomi yang melekat pada hak milik itu menimbulkan konsepsi kekayaan (property). Dengan konsep kekayaan itu maka negara memberikan perlindungan hukum terhadap merek tersebut. Pemilik merek perlu dilindungi eksistensinya secara hukum terhadap siapa saja yang menggunakannya tanpa ijin. ${ }^{4}$

\footnotetext{
${ }^{4}$ Besar, Sisi Keuntungan Pendaftaran Merek, business-law.binus.ac.id, 2018.
}

Pendaftaran merek bertujuan untuk memperoleh kepastian hukum dan perlindungan hukum terhadap hak atas merek. Merek memegang peranan yang sangat penting dalam kehidupan ekonomi, terutama dalam dunia perdagangan barang dan jasa untuk membedakan dengan produk lain yang sejenis dalam satu kelas. Kelas barang dan jasa adalah kelompok jenis barang dan jasa yang mempunyai persamaan sifat, cara pembuatan, dan tujuan penggunaanya. Pendaftaran merek merupakan alat bukti yang sah atas merek terdaftar, pendaftaran merek juga berguna sebagai dasar penolakan terhadap merek yang sama secara keseluruhan atau sama pada pokoknya yang dimohonkan oleh orang lain untuk barang atau jasa sejenis. Pendaftaran merek sebagai dasar mencegah orang lain memakai merek yang sama pada pokoknya atau secara keseluruhan dalam peredaran barang atau jasa. ${ }^{5}$

Adapun keharusan mendaftarkan merek tertuang di dalam undangundang sehingga untuk mendapatkan perlindungan merek, maka harus dilakukan pendaftaran. Dahulu sistem 
yang dianut adalah deklaratif artinya merek tidak perlu harus didaftarkan dan sudah dilindungi oleh hukum namun kini sudah berubah dengan mengunakan sistem konstitutif (first to file). Sifat pendaftaran merek konstitutif artinya hanya merek yang didaftarkan saja yang akan mendapatkan perlindungan hukum dan yang merek yang tidak didaftarkan tidak dilindungi oleh hukum. Dalam sistem pendaftaran konstitutif, prinsip penerimaan merek adalah first to file, artinya siapapun yang mendaftar lebih dahulu akan diterima pendaftaraannya dengan tidak mempersoalkan apakah si pendaftar benar-benar menggunakan merek tersebut untuk kepentingan usahanya. Hal ini juga untuk menjaga dari pemalsuan, pendomplengan, atau adanya kesamaan secara keseluruhan atau pada pokoknya dengan milik orang lain. ${ }^{6}$

Oleh karena itu, kesadaran untuk mendaftarkan merek oleh pelaku usaha, khususnya pelaku usaha UMKM perlu disosialisasikan lebih kencang lagi. Hal ini dilakukan agar dapat melindungi pemilik merek dari penyalahgunaan yang dilakukan pihak-pihak tidak

${ }^{6}$ Ibid. bertanggung jawab dan dapat membesarkan mereknya. Adapun alasan mengapa UMKM perlu mendaftarkan mereknya ke Direktorat Jenderal Kekayaan Intelektual (DJKI) yaitu: ${ }^{7}$

1. Memberi Perlindungan Hukum

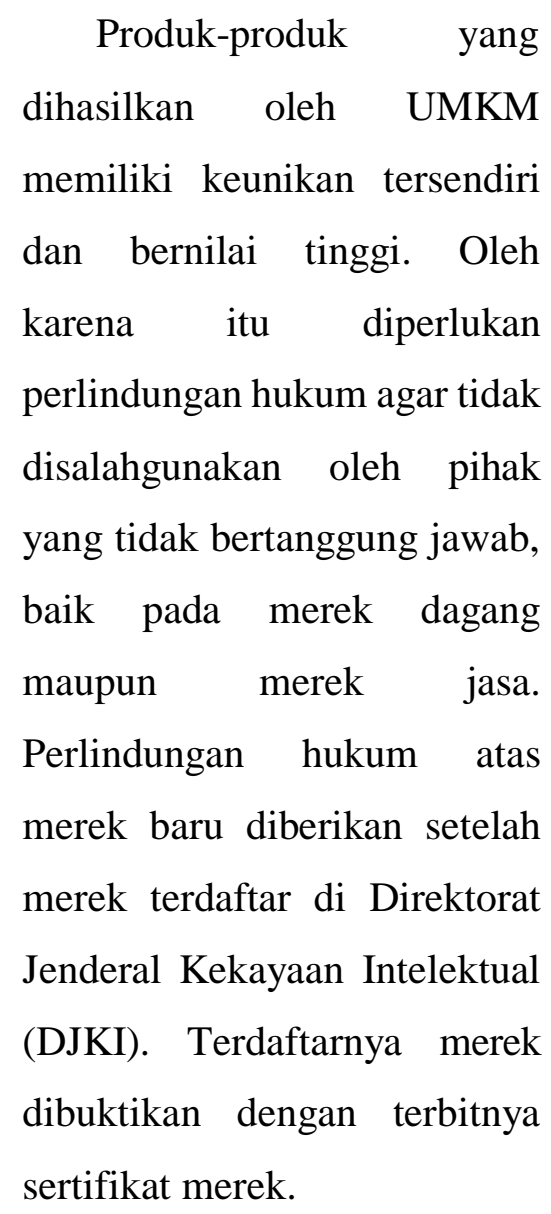

2. Sebagai Tanda Pembeda

Merek berperan sebagai identitas pembeda agar 
masyarakat dapat mengingat produk yang ditawarkan dan mampu membedakan dengan produk serupa dengan produknya.

3. Mendapatkan Hak atas Merek Dengan mendaftarkan merek, maka pemilik merek mendapatkan hak atas merek. Pemegang hak atas merek dapat menggunakan sendiri merek tersebut atau memberikan izin kepada pihak lain untuk menggunakannya, sehingga pihak lain yang ingin memproduksi barang dengan merek yang sama berkewajiban mendapatkan lisensi dari pemegang hak atas merek. Selain itu, pemegang hak atas merek juga dapat meminta pihak lain yang memproduksi barang dengan merek yang sama untuk membayar royalti atas penggunaan lisensi tersebut. Melalui hal ini dapat dilihat nilai ekonomis dari suatu produk yang dilindungi mereknya.
Selain itu juga, pendaftaran merek berfungsi sebagai: ${ }^{8}$

1. Alat bukti bagi pemilik yang berhak atas merek yang didaftarkan;

2. Dasar penolakan terhadap merek yang sama keseluruhan atau sama pada pokoknya yang dimohonkan pendaftaran oleh orang lain untuk barang/jasa sejenisnya;

3. Dasar untuk mencegah orang lain memakai merek yang sama keseluruhan atau sama pada pokoknya dalam peredaran untuk barang/jasa sejenisnya.

Ada beberapa keuntungan mendaftaran merek bagi siapa saja yang memiliki merek terkait dengan produk yang mulai dikenal oleh masyarakat. Dengan mendaftarkan merek berarti anda telah memiliki sebuah tanda yang berfungsi untuk membedakan dengan barang ataupun jasa lain yang dimiliki oleh pihak lain dan dilindungi oleh hukum. Beberapa 
Zarisnov Arafat

Vol. 3 No 2, Agustus 2021

ISSN 2657-0203

e-ISSN 2686-0244

${ }^{8}$ Ahmad Miru, Op.Cit, hlm. 7 
keuntungan atau manfaat apabila mendaftarkan merek yaitu: ${ }^{9}$

1. Menjaga

hak

Eksklusifitas.

Mendaftarkan merek berarti upaya tepat dan efektif untuk memastikan eksklusivitas hukum atas penggunaan nama atau logo dan lain lain. Sebagaimana hak kebendaan yang lainnya, merek memiliki hak eksklusifitas, yang dapat mencegah orang lain menggunakan mereknya.

2. Jangkauan perlindungan hukum.

Dengan mendaftarkan merek, maka akan diberikan perlindungan dalam cakupan nasional dan internasional untuk melakukan kegiatan bisnis.

\section{Menghalangi dan} mencegah pihak lain.

Dengan pendaftaran merek maka pemilik merek bisa melarang pelaku bisnis lain menggunakan merek yang mirip atau identik dengan merek yang dimilikinya.

4. Mengontrol penggunaan merek yang dimiliki dengan menggunakan mekanisme lisensi terhadap pihak lain.

5. Menikmati nilai ekonomis.

Memegang $r$ merek
terdaftar bisa
signifikan mempengaruhi
nilai kepada pembeli karena
setiap pembeli produk
cenderung membayar lebih
untuk goodwill yang
dibangunnya.

Perlindungan merek diberikan oleh pemerintah selama 10 (sepuluh) tahun dan bisa diperpanjang dengan membayar biaya pemeliharaan dengan catatan tidak ada perbedaan nama merek maupun jenis barang yang diproduksi dalam masa 10 (sepuluh) tahun. Pemohon hak merek terdiri dari:

1. Orang Perorangan;

2. Badan Hukum;

${ }^{9}$ Besar, Loc. Cit. 
3. Beberapa orang/ badan hukum (pemilikan bersama/ merek kolektif).

Untuk mengajukan pendaftaran merek dagang ke DJKI Kemenkumham dapat dilakukan secara daring (online) dengan mengakses website dgip.go.id dan menginputkan dokumen-dokumen yang dibutuhkan sesuai dengan ketentuan yang telah dibuat oleh Direktur Kekayaan Intelektual Kemenkumham seperti berikut: ${ }^{10}$

1. Mengajukan permohonan pendaftaran dalam rangkap 2 (dua) yang diketik dalam bahasa Indonesia dengan menggunakan formulir permohonan yang telah disediakan yang memuat:

a. Tanggal, bulan dan tahun permohonan;

b. Nama lengkap, kewarganegaraan, dan alamat pemohon;

c. Nama lengkap dan alamat kuasa, apabila pemohon diajukan melalui kuasa;

d. Warna-warna apabila merek yang dimohonkan pendaftarannya

menggunakan unsur-

unsur warna;

e. Nama negara dan tanggal

permintaan pendaftaran merek yang pertama kali dalam hal permohonan diajukan dengan hak prioritas.

2. Surat permohonan pendaftaran merek dilampiri dengan:

a. Fotokopi KTP, sedangkan bagi pemohon yang berasal dari luar negeri sesuai dengan ketentuan undang-undang harus memilih tempat kedudukan di Indonesia, biasanya dipilih pada alamat kuasa hukumnya;

b. Fotokopi akta pendirian badan hukum yang telah disahkan oleh notaris apabila permohonan diajukan atas nama badan hukum;

c. Fotokopi peraturan pemilikan bersama apabila permohonan diajukan atas nama lebih

${ }^{10}$ www.dgip.go.id 
dari satu orang (Merek Kolektif);

d. Surat kuasa khusus apabila permohonan pendaftaran dikuasakan;

e. Tanda pembayaran biaya permohonan;

f. 10 helai etiket Merek (ukuran maksimal 9x9 cm, minimal $2 \times 2 \mathrm{~cm}$ );

g. Surat pernyataan bahwa Merek yang dimintakan pendaftaran adalah miliknya.

Adapun merek yang tidak dapat didaftarkan di DJKI Kemenkumham apabila: ${ }^{11}$

1. Bertentangan dengan ideologi negara, peraturan perundangundangan, moralitas, agama, kesusilaan, atau ketertiban umum;

2. Sama dengan, berkaitan dengan, atau hanya menyebut barang dan/atau jasa yang dimohonkan pendaftarannya;

3. Memuat unsur yang dapat menyesatkan masyarakat tentang asal, kualitas, jenis, ukuran, macam, tujuan penggunaan barang dan/atau jasa yang dimohonkan pendaftarannya atau merupakan nama varietas tanaman yang dilindungi untuk barang dan/atau jasa yang sejenis;

4. Memuat keterangan yang tidak sesuai dengan kualitas, manfaat, atau khasiat dari barang dan/atau jasa yang diproduksi;

5. Tidak memiliki daya pembeda; dan/atau

6. Merupakan nama umum dan/atau lambang milik umum. Selain itu juga ada kemungkinan pendaftaran merek dapat ditolak, jika: ${ }^{12}$

1. Mempunyai persamaan pada pokoknya atau keseluruhannya dengan Merek milik pihak lain yang sudah terdaftar lebih dahulu untuk barang dan/atau jasa yang sejenis;

2. Mempunyai persamaan pada pokoknya atau keseluruhannya dengan Merek yang sudah 
Zarisnov Arafat

Vol. 3 No 2, Agustus 2021

ISSN 2657-0203

${ }^{11}$ www.dgip.go.id

${ }^{12}$ www.dgip.go.id e-ISSN 2686-0244 
terkenal milik pihak lain untuk barang dan/atau jasa sejenis;

3. Mempunyai persamaan pada pokoknya atau keseluruhannya dengan Merek yang sudah terkenal milik pihak lain untuk barang dan/atau jasa tidak sejenis sepanjang memenuhi persyaratan tertentu yang ditetapkan lebih lanjut dengan peraturan pemerintah;

4. Mempunyai persamaan pada pokoknya atau keseluruhannya dengan indikasi-geografis yang sudah dikenal;

5. Merupakan atau menyerupai nama orang terkenal, foto, atau nama badan hukum yang dimiliki orang lain, kecuali atas persetujuan tertulis dari yang berhak;

6. Merupakan tiruan atau menyerupai nama atau singkatan nama, bendera, lambang atau simbol atau emblem negara atau lembaga nasional maupun internasional, kecuali atas persetujuan tertulis dari pihak yang berwenang;
7. Merupakan tiruan atau menyerupai tanda atau cap atau stempel resmi yang digunakan oleh Negara atau lembaga pemerintah, kecuali atas persetujuan tertulis dari pihak yang berwenang.

Setelah diberikan pemahaman terkait dengan pentingnya pendaftaran merek terhadap produk makanan yang diproduksi oleh para usahawan/pelaku UMKM, maka selanjutnya diberikan kesempatan untuk mencoba mengakses website dengan alamat www.dgip.go.id untuk lebih mengenal bentuk-bentuk Hak Atas Kekayaan Intelektual dan mendapatkan pengarahan langsung dokumen-dokumen yang harus dilengkapi berikut dengan contohnya.

Adapun proses pendaftaran merek atas produk UMKM yang mereka buat, selanjutnya diarahkan untuk melakukan konsultasi lebih lanjut dengan ahli hukum agar tidak menemui kendala ataupun masalah, mengingat pendaftaran merek dagang yang dilakukan ini merupakan perbuatan hukum, maka sudah tentu akan menimbulkan akibat hukum di kemudian hari. Hal tersebut dilakukan 
oleh penulis agar meminimalisir akibat hukum yang merugikan pasca pendaftaran merek tersebut, karena dapat dipahami oleh penulis masih minimnya pengetahuan hukum masyarakat di Desa Klari, sehingga jika suatu saat nanti menghadapi masalah hukum di kemudian hari malah semakin membingungkan bagi mereka. Selain itu pula, dalam pendaftaran merek juga wajib dilakukan oleh Lembaga atau Badan Hukum yang memiliki legalitas dan fokus pada Hak Atas Kekayaan Intelektual (HaKI), yang mana menaungi konsultan HaKI dalam bertindak mengurusi hal tersebut, sehingga dengan langkah- langkah yang diarahkan tadi proses pendaftaran merek atas produk UMKM di Desa Klari dapat berhasil menjaga orisinalitas produk dan memperoleh kepastian hukum serta perlindungan hukum terhadap hak atas mereknya.

\section{KESIMPULAN DAN SARAN}

Berdasarkan kegiatan yang telah dilakukan, adapun hasil-hasil yang diperoleh adalah sebagai berikut:

\section{A. Kesimpulan}

1. Pendaftaran Merek dagang terhadap produk-produk
UMKM di Desa Klari terutama produk kuliner dianggap sangat penting mengingat belum adanya perlindungan terhadap produk orisinil (asli) karena mulai banyak produk tiruan sehingga bisa mengganggu proses penjualan produk asli (pelopor), selain itu pula antusiasme para penggiat usaha/pelaku UMKM untuk memproduksi produk dan belajar ilmu hukum sangat menunjang kegiatan ini.

2. Kurangnya kegiatan penyuluhan hukum terutama mengenai Hak Atas Kekayaan Intelektual dan keterbatasan pengetahuan aparatur pemerintah desa bisa menurunkan minat masyarakat untuk berkreasi dan berinovasi serta menghambat perputaran ekonomi di Desa Klari

\section{B. Saran}

1. Aparatur Pemerintah Desa harus lebih sering mengadakan kegiatan penyuluhan atau sosialisasi perihal pengetahuan hukum 
terhadap

masyarakat,

mengingat sebuah adagium $I b i$

Ius Ubi Societas yang mana

dapat diartikan di dalam

masyarakat pasti ada hukum,

sehingga hukum merupakan

hal penting yang harus

dipelajari semua masyarakat

sehingga dapat memberikan

manfaat dalam penerapannya.

2. Aparatur Pemerintah Desa harus lebih giat lagi mendukung setiap kegiatan masyarakat, terutama para pelaku UMKM baik secara moril maupun materiil yang mana memang sangat dirasakan sumbangsihnya untuk mengurangi angka pengangguran di Desa Klari.

\section{Buku}

\section{DAFTAR PUSTAKA}

Abdulkadir Muhammad, 2001, Kajian Ekonomi Hak Kekayaan
Intelektual, Cipta Aditya Bakti,
Bandung.

Ahmadi Miru, 2005, Hukum Merek Cara Mudah Mempelajari UndangUndang Merek, PT. RajaGrafindo Persada, Jakarta.

Besar, 2018, Sisi Keuntungan Pendaftaran Merek, businesslaw.binus.ac.id, diakses tanggal 10 Oktober 2020.

Budi Agus Riswandi dan M. Syamsudin, 2005, Hak Kekayaan Intelektual dan Budaya Hukum, PT. RajaGrafindo Persada, Jakarta.

Insan Budi Maulana, 1999, Perlindungan Merek Terkenal di Indonesia dari Masa ke Masa, PT. Citra Aditya Bakti, Bandung.

Lindsay, dkk, 2006, Hak Kekayaan Intelektual Suatu Pengantar, Asian Law Group \& Alumni, Bandung.

\section{Peraturan Perundang-undangan}

Kitab Undang-Undang Hukum Perdata

Undang-Undang Nomor 20 Tahun

2016 tentang Merek dan Indikasi

Geografis

\section{Sumber Lainnya}

www.prodeskel.binapemdes.kemendagr i.go.id

www.dgip.go.id 